\title{
Physics Teachers' Perception of Effective Teaching/Learning of Physics in Senior Secondary School for Global Competitiveness.
}

\author{
Agommuoh, Patience Chinyere (Ph.D) \\ Department Of Science Education, College Of Agricultural And Science Education, Michael Okpara University \\ Of Agrculture P.M.B 7267, Umudike Umuahia, Abia State, Nigeria
}

\begin{abstract}
For Nigerian education to aim at enhancing global competitiveness, physics education must ensure that it is translated into marketable product and processes. This study was designed to investigate physics teachers' perception of effective teaching/learning of physics in senior secondary schools for global competitiveness. The study therefore employed a descriptive survey design. The sample size for the study was seventy nine (79) Senior Secondary School physics teachers from Umuahia Education zone of Abia State of Nigeria. Two (2) research questions and one (1) null hypothesis tested at 0.05 level of significance guided the study. The instrument for data collection is a researchers' developed structured questionnaire of the Likert type. The instrument was validated and the reliability coefficient obtained as 0.79. Data collected was analyzed using mean for the research questions and chi-square $\left(X^{2}\right)$ statistics for the hypothesis. The study revealed that six main principles of effective teaching/learning for global competitiveness were identified by physics teachers. They include first dealing with students' existing ideas and conceptions, students been able to apply new concepts or skills into different contexts, and learning activities such as inquiring-based teaching and cooperative learning groups. It was recommended that physics teachers should utilize these principles for effective physics teaching/learning.
\end{abstract}

Keywords: Education, Physics, Effective teaching/learning and global competitiveness.

\section{Introduction}

The principal objective of education has been the development of the whole individual. The hope of every seasoned parent is that the school will be able to develop the child's potentialities in life. The only way to achieve this is by giving the child education that is of high quality and standard. Education involves the total efforts of the community to raise its political, social and economic standard of living. The implication of this is that it is an inevitable tool for surmounting ignorance, disease, poverty and to produce functional individuals who have positive attitudes towards the growth and development of the society.

The development of any nation depends largely on the level of its scientific and technological literacy. Physics which is one of the sciences is indispensable to technological advancement. Physics has helped in the development of modern technology through the application of its principles to modern invention. Its study enhances an understanding of the interplay of forces in nature because it forms veritable armour against superstition which muddles technological advancement anywhere. Physics as a course of study is perceived generally to be very interesting, vast, mathematical and experimental. Almost all aspect of life science, both living and nonliving has something to do with physics, ranging from engineering to mathematics, biology, chemistry. Physics is one of the pre-requisite subjects for the study of engineering, technological, medical and other applied science courses in the university. Its study instructs a person in the art of critical thinking, how to pose questions and how to solve problems. It also equips graduates with mathematical and information technology skills. The study of physics has been and will remain of tremendous importance to mankind because it is capable of explaining natural phenomenon and everyday occurrences. Physics is the most basic and fundamental of all the sciences and according to Adeyemi (2003) and Oraifo (2005), it plays a very important role in scientific and technological advancement that affects the lives of mankind. The implication of this is that Nigeria cannot develop technologically if the subject physics is not taught effectively in our secondary schools.

In spite of the Federal Government's efforts in trying to promote the teaching of physics in our secondary schools by providing science equipments, employing physics teachers and even sending physics teachers on in-service training, physics achievement still remains deplorable. This has resulted in poor performance of students in the subject. The poor performance of students in the West African School Certificate Examination as confirmed by the West African Examination Council Chief Examiners report (2000-2009) has caused concern to many well-informed Nigerians. This has led many researchers in physics education to search for the cause of this poor achievement in the subject and possible solutions to this problem. 
Competitiveness pertains to the ability and performance of an institution, a firm, sub-sector or country to sell and supply goods and services in a given market. According to The Global Competitiveness Report of the World Economic Forum (2012-2013) report, competitiveness is an important determinant for the well-being of states in an international trade environment. The report went further to explain that the concept of competitiveness has emerged as a new paradigm in economic development. Competitiveness captures the awareness of both the limitations and challenges posed by global competition, at a time when effective government action is constrained by budgetary constraints and the private sector faces significant barriers to competing in domestic and international markets. The Global Competitiveness Report of the World Economic Forum (2012-2013) defines competitiveness as the set of institutions, policies, and factors that determine the level of productivity of a country. The maintenance of competitiveness for development, hinges mainly on wellfunctioning public and private institutions, appropriate infrastructure, a stable macroeconomic framework, and good health and primary education.

As wages rise with advancing development, countries move into the efficiency-driven stage of development, when they must begin to develop more efficient production processes and increase product quality. At this point, competitiveness becomes increasingly driven by higher education and training, efficient goods markets, efficient labour markets, developed financial markets, the ability to harness the benefits of existing technologies, and its market size, both domestic and international. Finally, as countries move into the innovation-driven stage, they are only able to sustain higher wages and a higher standard of living if their businesses are able to compete by providing new or unique products. At this stage, companies must compete by producing new and different goods using the most sophisticated production processes, and through innovation. Recruiting and retaining highly qualified physics and physical science teachers is critical for maintaining global competitiveness. Physics education should ensure that it is translated into marketable product and processes, reinforced by strong intellectual property protection. Unfortunately, senior secondary school teachers are asked to teach science subjects they do not feel comfortable teaching and are not provided adequate guidance and support. Moreover, teachers often lack adequate pedagogical content knowledge to teach science effectively. Indeed educating students who are well- versed in physics is critical for preserving our economic competitiveness. The implication is that global competitiveness cannot be attained if physics is not taught effectively and properly in our senior secondary schools. Effective teaching is the teaching that successfully achieves the learning objectives by the pupils as identified by the teacher (Atilla CIMER, 2007). Atilla CIMER (2007) identified four attributes as important factors in the classroom in relation to effective teaching. The strength of each of these attributes determines how receptive pupils are to learning. These attribute are also identified as a key cause of success in the classroom. They are

1. Personality and will

2. Intelligence

3. Sympathy and tact

4. A sense of humour:

Studies in the past that have attempted to relate these attributes to educational outcomes, have completely ignored what actually happens in the classroom but had looked at the input characteristics such as the attributes of the teacher and students and also at the output such as the examination results and then tried to relate the two without considering what happens in the classroom. However more recent research on effective teaching has focused on activities in the classroom such as the students to which these personalities attributes help.

Based on the theoretical principles of constructivism which is a teaching approach that holds the view that knowledge are personally constructed and reconstructed by the learner based on his prior knowledge or experience, Atilla CIMER (2007) identified the main principles of effective teaching in physics as follows:

1. Dealing with students' existing ideas and conceptions

2. Encouraging students to apply new concepts of skills into different contexts

3. Encouraging students participation in lessons

4. Encouraging student inquiry

5. Encouraging co-operative learning among students.

Determining students' existing ideas and conceptions has been recognized as an important variable in physics teaching and a necessary part of teaching strategies developed ( Goodrum, Hackling and Rennie, 2002; Tytler, 2002a, 2002b). Hipkins (2002) argued that teaching science and physics is effective when students' existing ideas, values and beliefs, which they bring to a lesson, are elicited, addressed and linked to their classroom experiences at the beginning of a teaching programme. Students do not enter the classroom as empty vessels into which new ideas can be poured by teachers (Tyler, 2002a). Meaningful learning therefore occurs as students consciously and explicitly link their new knowledge to existing knowledge structure. The implication is that effective instructional approaches have to be based on what is already known by the learner. Determining students' existing ideas and conceptions in physics may also increase students' awareness of them which is 
necessary for meaningful learning (Goodrum, Hackling and Rennie, 2002). When students become aware of their previously 'tacit' ideas they have a chance to compare them with scientific ones and change if necessary. Through determining students existing conceptions, teachers can develop appropriate instructional strategies that move these unscientific ideas and conceptions towards scientific ones (Hipkins, 2002). Another technique for effective physics teaching is the encouragement of students to participate in lessons. Parkinson (2004) argued that for effective learning to take place, students are required to be active in the learning process. Daboer, (2002) also believes that the more students are involved in the learning process the more they learn the topic. Active learning techniques can empower students to make good decisions and take active role in their learning, increase their motivation and improve their knowledge acquisition. A fourth element of effective teaching of physics identifies is encouraging students inquiry Students engaging in inquiry during physics lesson have a lot of positive effects in their learning of the subject physics. These include students developing a wide range of skills such as psychomotor and academic or intellectual skills. Psychomotor skills we all know involves doing something physics, like gathering and setting up apparatus, doing the experiments, making observations, measuring and recording data and drawing graphs. Encouraging students to work or co-operate with each other in constructing their own understand is another principle of effective teaching identified. Co-operative learning groups promote community aspects of the classroom and the role of discussion with peers in helping students to learn physics. Peer-peer discussions in co-operative learning groups promote meaningful learning by helping learners to help each other to incorporate new experiences and information into their existing cognitive structures thereby fostering the development of deep understanding (Joyce, Weil and Calhonn 2000a). The implication is that students can learn from each other and develop a shared understanding of the topics they are learning. For Nigeria to possess competitive strengths to be prepared to ride out economic crises and provide rising and sustainable living standards to its citizens there is the need for physics to be taught effectively in our senior secondary schools so as to bring about the much desired scientific and technological advancement that affects the lives of mankind and hence enhance global competitiveness.

\section{Purpose of the Study:}

This study therefore investigated physics teachers' perception of effective teaching/learning of physics in senior secondary schools for global competitiveness.

\section{Research Questions}

The following research questions guided the study.

1. What are the mean scores of physics teachers' perception of effective teaching/learning of physics for global competitiveness?

2. What are the mean scores of male and female physics teachers' perception of effective teaching/learning of physics for global competitiveness?

\section{Hypothesis}

The null hypothesis below tested at 0.05 level of significance guided the study.

Ho$_{1}$ : There is no significant difference in the mean scores of male and female physics teachers' perception of effective teaching/ learning of physics for global competitiveness.

\section{Methodology}

The study adopted descriptive survey design. A sample of seventy-nine (79) physics teachers was used for the study. The instrument for data collection was a researcher's developed structured questionnaire of the Likert type on physics teachers' perception of effective teaching/learning of physics in senior secondary schools for global competitiveness. The responses are Strongly Agree (SA), Agree (A), Disagree (D), and Strongly Disagree (SD) weighted 4, 3, 2, and 1, respectively. It is a six-item questionnaire that is made up of principles that can be used for effective teaching/learning of physics to help students acquire scientific skills and knowledge for technological advancement and subsequently for global competitiveness. The instrument was validated and the reliability index was determined by cronbach alpha and found to be 0.79 . The questionnaires were distributed by the researcher and collected back to ensure 100 percent return. The research questions were answered using mean while the hypothesis was tested using chi-square statistics at 0.05 level of significance.

\section{Results}

The results in respect of mean scores of physics teachers perception of principles of effective teaching and learning of Physics for global competitiveness. got from the study are presented in tables 1 and 2 below. 
Table 1:

\begin{tabular}{|c|c|c|c|c|c|c|}
\hline \multirow{3}{*}{$\begin{aligned} \mathrm{S} / \mathrm{N} \\
1 .\end{aligned}$} & \multicolumn{6}{|c|}{$\begin{array}{l}\text { Table 1: } \\
\begin{array}{c}\text { Mean Scores of Physics Teachers Perception of Principles of Effective Teaching } \\
\text { and Learning of Physics for global competitiveness. }\end{array}\end{array}$} \\
\hline & ITEM & $\mathrm{A}$ & $\mathrm{D}$ & SD & & $(X)$ \\
\hline & $\begin{array}{l}\text { Dealing with students' existing } \\
\text { Ideas and conceptions. }\end{array}$ & 54 & 14 & 9 & 6 & 3.36 \\
\hline 2. & $\begin{array}{l}\text { Encouraging students to apply } \\
\text { new concepts of skills into } \\
\text { different contexts. }\end{array}$ & 54 & 12 & 8 & 5 & 3.46 \\
\hline 3. & $\begin{array}{l}\text { Encouraging students participation } \\
\text { in lessons. }\end{array}$ & 59 & 16 & 4 & - & 3.70 \\
\hline 4. & Encouraging student inquiry & 70 & 9 & - & - & 3.89 . \\
\hline 5. & $\begin{array}{l}\text { Encouraging co-operative learning } \\
\text { among students. }\end{array}$ & 62 & 9 & 7 & 1 & 3.67 \\
\hline
\end{tabular}

Result in table 1 above shows that all the items have mean between 3.36 and 3.89. This shows that all the physics teachers agree that all these activities will contribute to effective teaching and learning of physics for global competitiveness.

Table 2:

\section{Mean Scores of Male and Female Teachers Perception of Principles of Effective Teaching and Learning of Physics for Global Competitiveness.}

$\begin{array}{lcccccc} & & \text { SA } & \text { A } & \text { D } & \text { SD } & \text { TOTAL } \\ \text { MALE. } & 57 & 237 & 33 & 15 & - & 285 \\ & & (212) & (52) & (20) & & \\ \text { FEMALE } & 22 & 62 & 40 & 13 & - & 115 \\ & & (86) & (21) & (8) & & \end{array}$

$\begin{array}{lllll}299 & 73 & 28 & - & 402\end{array}$

$\begin{array}{lc}\text { TOTAL } & 299 \\ \mathrm{X}^{2} \mathrm{cal}=38.10, \mathrm{X}^{2} \mathrm{tab}=7.82, \mathrm{df}=3\end{array}$

Since $\mathrm{X}^{2}$ cal (38.10) is more than $\mathrm{X}^{2} \operatorname{tab}(7.82)$, the null hypothesis is rejected. This means that there is a significant difference between the opinion of males and females as to the principles for effective teaching and learning of physics for global competitiveness.

\section{Discussion}

From table 1, all the items had mean values between 3.36 and 3.89 which is above 2.5 showing that all the physics teachers opined that all the items are principles for effective teaching and learning of physics for global competitiveness. This is in agreement with Trowbridge, Boybee and Powell (2000) who opined that for effective learning to occur, teachers should first identify students' prior ideas, make students aware of them and, in the light of these ideas, help students construct their own understanding after which teachers are to provide opportunities for students to apply their newly acquired knowledge to different situations. This is also in agreement with. Taras (2002) who is of the opinion that student - centred learning has promoted and brought about greater student participation and involvement and this can be achieved by taking into consideration the course of the lesson. Also this is in line with Stepanek, (2000) who suggested that is for cognitive conflict to be fostered in students, they need opportunities to pose questions about physics, to work with others, to conduct investigations, present and defend their ideas, solutions and findings and assess their own and other students' reasoning.

From table 2, it is observed that the hypothesis was rejected and the alternative accepted which means that gender played a role.

\section{Conclusion}

Enhancing global competitiveness is necessary for Nigeria to stabilize its economic growth and ensure a rising prosperity for its population going into the future. This can be achieved by educating students who are well- versed in physics. The implication is that physics has to be taught effectively. The study revealed that for effective teaching and learning of physics to occur, teachers have to be exposed to six principles of effective teaching in physics which are dealing with students existing ideas and conception, encouraging students to apply new concepts or skills into different contexts, encouraging students' participation in lesson, encouraging students inquiring and encouraging co-operative learning among students 


\section{Recommendation}

For the enhancement of global competitiveness and the accomplishment of these principles, the following recommendations are made.

1. Classroom teachers are advised to use teaching methods and activities as question and answer, discussions which can be either for small group or whole class, practical work and ICT facilities.

2. Students should be encouraged to participate fully in the learning process.

3. Classroom teachers are advised to encouraging students to work or co-operate with each other in constructing their own knowledge to improve students understanding and learning.

\section{References}

[1]. S.O. Adeyemi Studies of the effect of aptitude instructional leadership styles and Learning environment on students' achievement in physics. Unpolished Ph. D Thesis, University of Lagos, Nigeria. 2003.

[2]. S.O. Oraifo Teaching Methodologies in Science and Technology Education. In U.M.O. Ivowi (ed) Science and Technology education for Department 2005 pp.1-24. Lagos: NERDC Press.

[3]. Atilla Cimer Effective Teaching in Science: A Review of Literature: Journal of Turkish Science Education, 2007, Volume 4, Issue 1.

[4]. D. Goodrum, M. Hackling, and L. Rennie. The Status and Quality of Teaching and Learning of Science in Australian Schools. Canberra: Department of Education Training and Youth Affairs, 2001.

[5]. R.Tytler. Teaching For Understanding In Science: Constructivist/Conceptual Change Teaching Approaches, Australian Science Teachers Journals, 2000a, 48 ,3:14-21.

[6]. R.Tytler. Teaching For Understanding In Science: Constructivist/Conceptual Change Teaching Approaches, Australian Science Teachers Journal, 2000b, 48 (4) , 30-35

[7]. R. Hipkins. Curriculum, Learning and Effective Pedagogy. A Literature Review in Science Education. Wellingtin: Ministry of Education.,2002.

[8]. J. Parkinson. Improving Secondary Science Teaching London: Routledge Falmer, 2004

[9]. G. E. Daboer. Student-Centred Teaching In A Standards-Based World: Finding a Sensible Balance, Science \& Education, 2002, 11:405-417.

[10]. B. Joyce, M. Weil, and E. Calhoun. Models of Teaching Boston: Allyn and Bacon.2000a

[11]. L. W. Trowbridge, R, W. Bybee and J. C. Powell. Teaching Secondary School Science, Upper Saddles River, NJ: Merrill/Prentice Hall, 2000.

[12]. N. Taras. Using Assessment For Learning And Learning From Assessment, Assessment \& Evaluation in Higher Education, 2002, 27(6).: 501-510.

[13]. J. Stepanek. Mathematics And Science Classrooms: Building a Community Of Learners, Northwest Regional Educational Laboratory U.S. Dept. Of Education, Office of Educational Research and Improvement $\backslash$ Educational Resources Information Centre, 2000.

[14]. World Economic Forum. The Global Competitiveness Report 2011-2012 Geneva: World Economic Forum, 2011. 